\title{
Pemanfaatan Sabun Antiseptik Herbal sebagai Upaya Menjaga Kesetabilan Ekonomi dan Kesehatan Selama Pandemi di Kelurahan Merjosari Malang
}

\author{
Nur Kusmiyati ${ }^{1}$, Anik Listiyana ${ }^{2}$, Nuzulul Furoida Imarotu Zahroh ${ }^{3}$, Septian Tri Wijaksono ${ }^{4}$ \\ 1,3,4Program Studi Biologi, UIN Maulana Malik Ibrahim Malang \\ ${ }^{2}$ Program Studi Ilmu Kedokteran, UIN Maulana Malik Ibrahim Malang \\ kusmiy4tinur@gmail.com,anik.listiyana@kedokteran.uin-malang.ac.id, \\ 17620023@student.uin-malang.ac.id, septian.tri1996@gmail.com
}

\section{Info Artikel \\ Riwayat Artikel: \\ Diterima: Agustus 2021 \\ Direvisi: Agustus 2021 \\ Diterbitkan: September 2021}

\section{Keywords:}

Antiseptic

Merjosari

Soap

Herbs

\begin{abstract}
The women in Merjosari Village RW 05 Lowokwaru Malang are housewives and have a low income on average. The community complained about the difficulty of earning income and finding work during a pandemic like this because most of the husbands (heads of families) were laid off. For this reason, the community is required to do business independently, one of which is making antiseptic soap by utilizing herbal plants that grow in front of the house as an effort to maintain family economic stability and health during the pandemic. The method used is the preparation of activities, socialization, training and mentoring. Evaluation is done by observing the performance of each participant at the end of the activity. The achievement indicator used to declare the success of the service is if each participant has been able to make or produce at least one antiseptic soap from herbal plants. In addition, it is also assessed from the results of the pre-test and post-test. The community of RW 05 Merjosari Village, Lowokwaru District, Malang City can take advantage of ethnopharmaceutical medicinal herbs. Participants have succeeded in producing antiseptic soap from herbal gardens planted around their homes as local products. The implementation of programs with themes or topics carried out by the Team can be recommended to other places or schools or carried out in Islamic boarding schools.
\end{abstract}

Copyright $(2021$ JRCE. All rights reserved.

\section{Korespondensi:}

Nur Kusmiyati,

Program Studi Biologi, UIN Maulana Malik Ibrahim Malang

Jl. Gajayana No. 50, Kec. Lowokwaru, Kota Malang, Jawa Timur 65144

kusmiy4tinur@gmail.com

\section{PENDAHULUAN}

Status pandemi infeksi penyakit coronavirus 2019 (COVID-19) telah mencapai 1.696.588 kasus di seluruh dunia, dengan angka kematian 6,24\% [1]. Di Indonesia sendiri, lebih dari 3.000 orang positif COVID-19. Berbagai hal dilakukan untuk menangkal penularan virus ini seperti menerapkan protokol kesehatan dengan cara memakai masker, menjaga jarak, menghindari kerumunan dan mencuci tangan menggunakan sabun. Penggunaan sabun antiseptik bertujuan untuk membunuh mikroorganisme yang ada di tangan. Hal tersebut menyebabkan sabun menjadi kebutuhan utama yang dapat digunakan sebagai pembersih dan pendukung kesehatan kulit tangan, wajah maupun tubuh [2].

Sabun berbahan kimia secara terus menerus menimbulkan masalah tambahan seperti kerusakan ekologi dan tubuh [3]. Solusi yang dapat digunakan untuk menyelesaikan masalah adalah subtitusi sabun kimia dengan bahan nabati atau alami yang memiliki efek antiseptik. Beberapa tanaman rumah tangga yang banyak ditemukan di depan rumah seperti kemangi, sereh, sirih dan salam dinyatakan memiliki aktivitas antimikroba terbaik pada bagian daunnya [4]. Tanaman tersebut merupakan tanaman herbal yang bekhasiat 
sebagai antimikroba, antidiare, antioksidan, antihipertensi, antikolesterol dan antidiabetik [5]. Pada uji pendahuluan menunjukkan bahwa ekstrak daun kemangi, sereh, sirih dan salam dapat menghasilkan zona hambat pada Staphylococcus aureus dan Escherichia coli.

Sebagian besar Ibu-ibu di Kelurahan Merjosari RW 05 Lowokwaru Malang merupakan ibu rumah tangga dan rata-rata memiliki penghasilan rendah. Masyarakat tersebut mengeluhkan tentang sulitnya mendapatkan penghasilan dan mencari pekerjaan di masa pandemi seperti ini karena sebagian besar suami (kepala keluarga) terkena PHK. Menurut Sekretaris Menteri Koordinator Bidang Perekonomian, Susiwijono menyebut kondisi pandemi Covid-19 berpengaruh pada perekonomian masyarakat. Selain hal itu, biaya hidup dan kebutuhan pokok juga semakin mahal. Untuk itu, masyarakat dituntut melakukan usaha secara mandiri salah satunya dengan pembuatan sabun antiseptik dengan memanfaatkan tanaman herbal yang tumbuh di depan rumah sebagai upaya menjaga kesetabilan ekonomi keluarga dan kesehatan selama pandemi.

\section{METODE PENELITIAN}

Kegiatan pengabdian ini dilaksanakan melalui dua tahap: Pada tahap pertama dilaksanakan sosialisasi pemanfaatan tanaman herbal untuk pembuatan sabun antiseptik kepada Ibu-ibu Kelurahan Merjosari RW 05 Lowokwaru Malang. Selanjutnya pada tahap kedua kegiatan pengabdian ini adalah pelatihan dan pendampingan melalui praktek pembuatan sabun antiseptik dari tanaman herbal (Gambar 1).

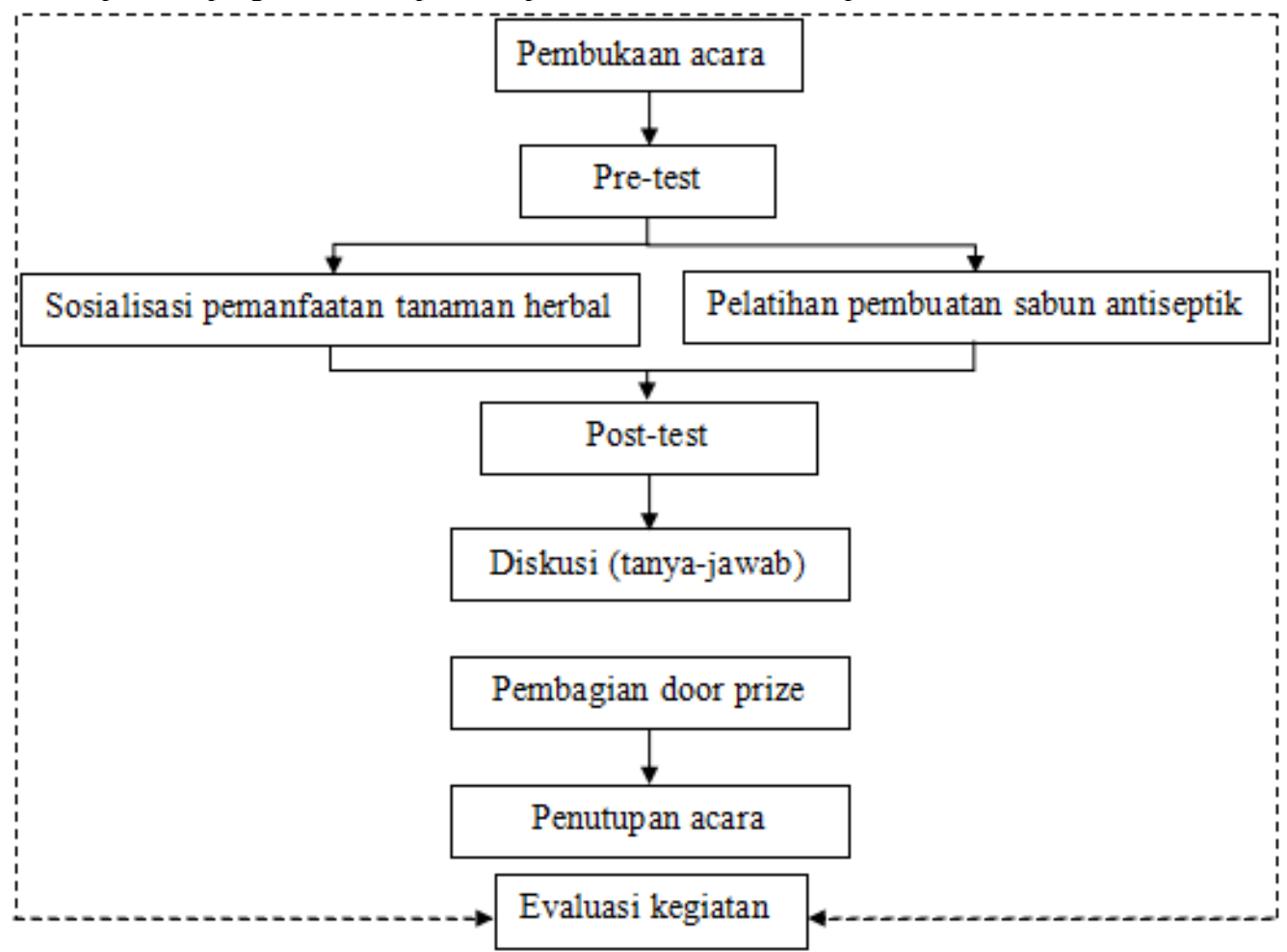

Gambar 1. Skema singkat alur pelaksanaan kegiatan pengabdian masyarakat pelatihan pembuatan sabun antiseptik herbal

Pada tahap pertama, sebelum dilaksanakan sosialisasi dilakukan kegiatan pretest untuk mengukur kemampuan peserta sebelum mendapatkan teori. Metode ceramah dan pembagian brosur (leaflet) digunakan dalam pelaksanaan kegiatan sosialisasi. Pada tahap kedua dilaksanakan dengan metode demo tentang pembuatan sabun antiseptik dengan bahan aktif (bahan utama) berupa tanaman herbal. Praktek pembuatan sabun dilaksanakan oleh tim dosen dan mahasiswa pengabdian. Demo tentang praktek pembuatan sabun ini juga sekaligus melibatkan Ibu-ibu Kelurahan Merjosari RW 05 Lowokwaru Malang yang merupakan peserta pelatihan masyarakat. Ibu-ibu tersebut diberi kesempatan untuk mencoba langsung pembuatan sabun antiseptik herbal tersebut.

Setelah pemberian materi yang berupa sosialisasi dan praktek pembuatan sabun, selanjutnya kegiatan ini diakhiri dengan post test untuk melihat tingkat keberhasilan sosialisasi. Pada akhir kegiatan ini dilakukan sesi tanya jawab dan pembagian doorprize untuk diberikan kepada peserta yang paling aktif. Sesi 
tersebut dilakukan pada akhir kegiatan. Evaluasi kegiatan dilakukan dengan melihat nilai pretest dan post test peserta, kemudian dilakukan analisis statistika paired t test terhadap data yang diperoleh.

Metode pelaksaan terdiri dari

1. Persiapan kegiatan meliputi:

a. Kegiatan survey pengabdian masyarakat di Kelurahan Merjosari RW 05 Lowokwaru Malang.

b. Permohonan ijin kegiatan, proses administrasi dan diskusi mengenai teknis pengabdian masyarakat disesuaikan dengan kondisi pandemi. Koordinasi dilaksanakan dengan Bapak Ketua RT Bapak Sueb untuk menyesuaikan kondisi selama pandemi.

2. Kegiatan sosialisasi, pelatihan dan pendampingan meliputi:

a. Sosialisasi dilakukan mengikuti protokol kesehatan selama pandemi dan tetap menjaga efektivitas kegiatan pengabdian masyarakat yang tepat sasaran.

b. Pelatihan yang dilakukan berupa simulasi rangkaian alat dan bahan yang diperlukan baik melalui video tutorial dan praktek langsung bersama Ibu-ibu Kelurahan Merjosari RW 05 Lowokwaru Malang.

c. Pendampingan dilakukan menggunakan pendekatan ke setiap kelompok yang melaksanakan praktek pembuatan sabun antiseptik dengan memperhatikan beberapa hal seperti persediaan bahan dan hasil dari pembuatan sabun antiseptik

3. Penutupan:

a. Penutupan kegiatan salah satunya melalui evaluasi kegiatan, hasil evaluasi berupa peningkatan pemahaman melalui kuisioner pre/post tes.

b. Apresiasi terhadap Ibu-ibu Kelurahan Merjosari RW 05 Lowokwaru Malang dapat dilakukan melalui pembagian door prize.

Evaluasi dilakukan dengan mengamati kinerja setiap peserta pelatihan pada akhir kegiatan. Indikator pencapaian yang ditetapkan untuk menyatakan keberhasilan pengabdian adalah apabila setiap peserta sudah dapat membuat atau menghasilkan minimal satu buah sabun antiseptik dari tanaman herbal. Selain itu, juga dinilai dari hasil pre test dan post testnya.

\section{HASIL DAN PEMBAHASAN}

Kegiatan pengabdian masyarakat oleh tim UIN Mengabdi Qaryah Thayyibah Tahun 2021 dilaksankaan secara offline sesuai dengan protokol kesehatan yang menyesuaikan kegiatan ibu-ibu RW 05 Kelurahan Merjosari, Kecamatan Lowokwaru, Kota Malang. Bentuk kegiatan meliputi sosialisasi, penyuluhan dan pelatihan (praktek) serta pendampingan. Kegiatan itu dilakukan empat kali di rumah RT 03 RW 05. Kegiatan penyuluhan bertujuan memberikan ilmu secara teoritis dan menambah wawasan bagi ibuibu peserta pelatihan masyarakat dengan materi meliputi pentingnya menjaga kebersihan, pemanfaatan tanaman-tanaman herbal serta pemanfaatan tanaman herbal menjadi sabun antiseptik. Penyuluhan ini akan disampaikan dalam bentuk ceramah dan tanya jawab kepada peserta oleh tim UIN Mengabdi Qaryah Thayyibah Tahun 2021 UIN Maulana Malik Ibrahim Malang.

Kegiatan lain yang diberikan berupa pelatihan terkait dengan materi atau topik pengabdian yang telah disebutkan. Praktek atau pelatihan bertujuan untuk memberikan keterampilan berupa skill sehingga peserta mahir mempraktekkan perakitan instrument dan pengolahan bahan atau media yang digunakan. Bentuk kegiatan ini dilaksanakan dengan menerapkan protokol kesehatan serta memaksimalkan petunjuk satgas Covid-19.

Proses pemberdayaan masyarakat dalam pembuatan sabun antiseptik dengan memanfaatkan tanaman-tanaman herbal tidak memiliki hambatan yang berkaitan dengan kajian teori. Hal ini dikarenakan adanya beberapa penyesuaian teori dengan aplikasi di masyarakat secara nyata. Salah satu penyesuaian teori adalah pembuatan air steril yang pada teori pendidikan biasanya dilakukan dengan proses penyulingan akan tetapi dapat dilakukan dengan perebusan sampai mendidih. Secara teori, air steril dapat juga dilakukan dengan cara merebus sampai mendidih. Hasil penelitian juga menunjukkan tidak adanya pertumbuhan bakteri pada hasil rebusan air tersebut. Setelah ditinjau di lapangan, proses pembuatan air steril di lapangan dapat dilaksanakan. Oleh sebab itu, adanya komunikasi dari pihak ibu-ibu PKK kepada stakeholder ditujukan untuk mengatasi permasalahan. Sebagai alternatif, pembuatan air steril dilakukan secara tradisional dengan merebus air sampai mendidih.

Sabun antiseptik dari tanaman-tanaman herbal yang ada disekitar rumah warga RW 05 Kelurahan Merjosari, Kecamatan Lowokwaru, Kota Malang dapat diproduksi secara masal oleh masyarakat tersebut. Selain sabun cuci tangan warga tersebut juga dapat mengembangkannya menjadi beberapa sabun yang lain seperti sabun cuci piring atau peralatan dapur. Selain itu, tanaman herbal tersebut juga dapat dimanfaatkan sebagai minuman kesehatan yang dikembangkan menjadi bentuk wirausaha dan diproduksi secara masal, karena ketersediaan bahan baku. Pada masa pandemi seperti ini, tidak hanya menerapkan protokol kesehatan 
tetapi juga meningkatkan daya tahan tubuh dengan mengonsumsi tanaman-tanaman herbal yang mumpuni di wilayah tersebut.

\subsection{Diskusi Data}

Outcome dari kegiatan ini adalah diperolehnya pengetahuan dan kemampuan ibu-ibu PKK RW 05 Kelurahan Merjosari, Kecamatan Lowokwaru, Kota Malang tentang pemanfaatan dan pengolahan tanaman herbal menjadi sabun antiseptik untuk menunjang pendapatan dan kesehatan keluarga. Di samping itu, diharapkan ibu-ibu PKK sesudah mengikuti kegiatan adalah perubahan mental dari kurang antusias dalam pengolahan dan pemanfaatan tanaman herbal menjadi antusias dan produktif mendayagunakan sumber daya alam yang ada di lingkungan sekitar sebagai bentuk perwujudan rasa syukur atas karunia Allah SWT.

Pembuatan sabun antiseptik dari tanaman herbal merupakan alternatif usaha yang menguntungkan karena cara pembuatannya sederhana, dan tidak membutuhkan biaya mahal [6]. Oleh karena itu, perlu pendampingan cara produksi dalam jumlah banyak. Pembuatan sabun antiseptik dari bahan tanaman-tanaman herbal belum banyak dikenal oleh masyarakat, dan produk ini belum banyak tersedia di pasaran sehingga peluang usaha pembuatan sabun antiseptik tersebut terbuka sangat lebar. Selain itu, pembuatan sabun antiseptik tersebut dapat meningkatkan pendapatan masyarakat dan menambah lapangan kerja. Pemberian penyuluhan terkait penyajian dan pengemasan juga diperlakukan sehingga lebih menarik dan dapat dijadikan usaha kecil-kecilan untuk meningkatkan nilai ekonomi. Kegiatan sosialiasasi tentang sabun antiseptik dari tanaman herbal akan memberikan wawasan bahwa tanaman herbal yang ada disekitar rumah mampu dimanfaatkan untuk produk yang lebih bernilai tinggi.

Dengan melihat dan menganalisis kondisi yang ada di RW 05 Kelurahan Merjosari, Kecamatan Lowokwaru, Kota Malang, maka beberapa program yang dilakukan melalui proses diskusi, pelatihan, pendampingan, dan monitoring terkait peningkatan nilai jual tanaman herbal. Monitoring dan evaluasi menjadi salah satu tahap untuk mengevaluasi sebuah program [7]. Salah satu bentuk evaluasi yaitu menilai respon peserta pembuatan sabun antiseptik. Nilai respon tersebut disajikan pada Tabel 1 .

Tabel 1. Respon peserta pelatihan pada pengabdian pembuatan sabun antiseptik

\begin{tabular}{llrrrr}
\hline \multirow{2}{*}{ No } & \multicolumn{1}{c}{ Aspek yang dinilai } & \multicolumn{3}{c}{ Nilai kuesioner $(\boldsymbol{\%})$} \\
\cline { 3 - 6 } & & $\mathbf{4}$ & $\mathbf{3}$ & $\mathbf{2}$ & $\mathbf{1}$ \\
\hline 1 & Topik pelatihan & 100 & 0 & 0 & 0 \\
\hline 2 & Kejelasan pemateri dalam pelatihan & 95 & 5 & 0 & 0 \\
\hline 3 & Jawaban pemateri terhadap pertanyaan peserta & 98 & 2 & 0 & 0 \\
\hline 4 & Kesesuaian materi dengan tujuan pelatihan pada pengabdian & 100 & 0 & 0 & 0 \\
\hline 5 & Kesempatan peserta untuk aktif bertanya dan berpendapat & 97 & 3 & 0 & 0 \\
\hline 6 & Tingkat kemungkinan materi bisa diterapkan di lokasi setiap & 100 & 0 & 0 & 0 \\
\hline 7 & Keserta pelatihan & 100 & 0 & 0 & 0 \\
\hline 8 & Sabun antiseptik (kualitas dan penyajian) & 90 & 10 & 0 & 0 \\
\hline 9 & Kemanfaatan kegiatan dalam menunjang ekonomi peserta & 100 & 0 & 0 & 0 \\
\hline 10 & Metode pelatihan yang diterapkan & 90 & 10 & 0 & 0 \\
\hline
\end{tabular}

4= sangat baik; $3=$ baik; $2=$ cukup; $1=$ kurang

Semua peserta pelatihan pembuatan sabun antiseptik dari tanaman herbal memberikan respon nilai yang sangat baik. Hal ini ditunjukkan dari aspek yang dinilai seperti topik pelatihan, kesesuaian materi dengan tujuan pelatihan, tingkat kemungkinan materi bisa diterapkan di lokasi masing-masing dan kemanfaatan kegiatan dalam menunjang ekonomi. Selain aspek tersebut, rata-rata nilai yang didapatkan sekitar 90-98\%.

Peningkatan nilai ekonomi tanaman-tanaman herbal melalui diversifikasi produk di RW 05 Kelurahan Merjosari, Kecamatan Lowokwaru, Kota Malang, memiliki harapan dapat menghasilkan beberapa perubahan bagi masyarakat di desa tersebut. Perubahan yang ada terutama terkait adanya pemahaman pengetahuan dan keterampilan yang dibutuhkan terkait diversifikasi produk tanaman-tanaman herbal. Perubahan tersebut bermanfaat untuk memberikan alternatif pilihan bagi masyarakat untuk memanfaatkan tanaman herbal. Capaian jangka panjang berupa terwujudnya perkampungan sabun antiseptik dari tanaman herbal melalui diversifikasi produk tersebut tentu membutuhkan proses dan waktu yang tidak singkat. Oleh karena itu proses pendampingan menjadi kebutuhan yang lain selain pengetahuan dan keterampilan terkait diversifikasi produk tanaman herbal. Proses pendampingan tersebut diperlukan untuk menjaga keberlanjutan program yang diberikan sampai benar-benar terwujud perkampungan sabun antiseptik dengan memanfaatkan tanaman herbal yang sesungguhnya. 


\subsection{Follow Up}

Tindak lanjut yang perlu dilakukan dari pengabdian masyarakat tentang pemanfaatan tanaman herbal sebagai sabun antiseptik untuk menjaga kestabilan ekonomi dan kesehatan selama pandemi adalah:

1. Pemantauan ketersediaan bahan baku yang berupa tanaman herbal.

2. Pembuatan sabun antiseptik dari tanaman herbal yang dapat dimanfaatkan dalam skala rumah tangga, minimal untuk menerapkan gaya hidup sehat dengat cara cuci tangan.

3. Membantu pemasaran produk sabun antiseptik.

Adapun manajemen pelaksanaan kegiatan produksi sudah diolah dan ditata oleh ibu-ibu PKK RW 05 Kelurahan Merjosari, Kecamatan Lowokwaru, Kota Malang sebagai sasaran perwakilan yang menerima sosialisasi sekaligus pembinaan selama pelaksanaan pengabdian masyarakat berlangsung.

\section{KESIMPULAN}

Masyarakat RW 05 Kelurahan Merjosari, Kecamatan Lowokwaru, Kota Malang dapat memanfaatkan tanaman herbal yang tumbuh disekitar rumah sebagai sabun antiseptik. Beberapa permasalahan yang terjadi selama proses pelaksanaan pendampingan kepada peserta pelatihan dapat diatasi dengan melakukan penyesuaian antara teori dengan realita masyarakat. Proses produksi dilaksanakan secara mandiri oleh masyarakat RW 05 Kelurahan Merjosari, Kecamatan Lowokwaru, Kota Malang dengan pemantauan jarak jauh dan pemasaran produk dibantu oleh pihak stakeholder. Pelaksanaan program dengan tema atau topik yang dilakukan oleh Tim dapat direkomendasikan ke tempat lain atau sekolah maupun dilakukan di pondok pesantren.

\section{UCAPAN TERIMAKASIH}

Terimakasih kepada LPPM UIN Maulana Malik Ibrahim Malang yang telah memberikan pendanaan pada program UIN Mengabdi Qaryah Thayyibah Tahun Anggaran 2021 dan pihak-pihak terkait yang mendukung berlangsungnya pengabdian.

\section{DAFTAR PUSTAKA}

[1] WHO. Coronavirus disease 2019 (COVID-19) Situation Report-83. Availableathttps://www.who.int/docs/defaultsource/coronaviruse/situationreports/20200412-sitrep-83covid-19.pdf?sfvrsn=697ce98d_4. 2020.

[2] Anggraini, D., Rahmides, W.S. dan Malik, M. Formulasi sabun cair dari ekstrak batang nanas (Ananas comosus. 1) untuk mengatasi jamur Candida albicans. Penelit Farm Indones. 1(01): 30-3. 2012.

[3] Djatmiko, M., Soebagyo, S.S., Pramono, S. dan Martono, S. Optimization of celery (Apium graveolens L.) herb extract granule production using Fluidized Bed Granulator. Indones J Pharm. 918. 2009.

[4] Sumardjo, D. Pengantar Kimia Buku Panduan Kuliah Mahasiswa Kedokteran. In EGC. 2009.

[5] Suryana, D. Cara Membuat Sabun: Cara Praktis Membuat Sabun. CreateSpace Independent Publishing Platform. 2013.

[6] Suryo, J. Herbal Penyembuh Gangguan Sistem Pernapasan: Pneumonia-Kanker Paru-ParuTBBronkitis-Pleurisi. Bentang Pustaka. 2010.

[7] Wawan, A. dan Dewi, M. Teori dan pengukuran pengetahuan, sikap dan perilaku manusia. Yogyakarta Nuha Med. 11-8. 2010. 